\title{
Comparison between Residential and Non-Residential Soccer Players Physical Fitness
}

\author{
Seth Ayensu Bortsie, Richmond Stephen Sorkpor, Josiah Ampiah \\ Regional Education Office- Central Region. Cape Coast. Ghana \\ Tutor, OLA College of Education, Cape Coast. Ghana \\ Tutor, Holy Child College of Education, Takoradi, Ghana.
}

\begin{abstract}
The study sought to investigate whether there are differences in the skill-related fitness levels of residential and non-residential juvenile soccer clubs in Central and Greater Accra Regions of Ghana. The study employed the descriptive survey design involving 116 respondents. The data collected was analyzed using descriptive statistic. It was revealed that residential status does not influence agility, coordination and power but rather speed and reaction time. Non-residential status influence dynamic balance positively than any other component in skill-related fitness. Non-residential clubs go through long training hours that influences better results and other factors like diet, body composition and development of life, have influence on power, coordination, agility and balance than their counterparts, even though two components out of the four are not significant. Based upon the findings of the research it is recommended that, Coaches should update their knowledge on modern strategies in training youth players as well as identifying their strengths and weakness in skill-related fitness and make use of them appropriately.
\end{abstract}

Key Words: Agility, Dynamic Balance, Coordination, Power, Reaction time, Speed

\section{Introduction}

Siedentop (2001) mentioned that research in exercise science, medical sciences, and health has led to a changing concept of physical fitness - one that is not only more meaningful but also more useful in providing directions for sport, fitness, and physical-education professionals as they implement programmes designed to help children, youths, and adults of all ages improve their fitness. Fitness is currently viewed as a series of components, each of which is specific in terms of its development and maintenance. Typically, fitness components are divided into two basic categories: those essentially related to health and those related to motor-skill performance. According to Hopkins (1998) training is a complex behaviour because it varies over a time frame ranging from seconds to years. Coaching of juvenile soccer in Ghana continues to produce some of the best players in the world who possess great technical and foot skills irrespective of training facilities and equipments. Afranie (2010) stated that many talents identified from the various talent hunts have gone waste due to the absence of strong structures that will see to their development and the country has now become the losers.

Youth soccer training, the bedrock of future talents for the nation, seems to be having problems with its preparation as regards quality training schedules, technical personnel, age disparities and consciousness of concept of skill-related fitness. Appropriate strength training system and programme, whether for a novice or advanced trainee, normally begins with a battery of general and specific performance testing protocols (health-related verses skill-related fitness). Long (2007) mentioned that testing certain performance parameters gives valuable information to the strength of a coach or personal trainer as to which training system or programme is most appropriate for the selected young athlete and trainee. These laudable ideas about appropriate training programmes are news yet to be revealed to some Ghanaian youth soccer coaches. Most of these juvenile soccer coaches are in the job out of interest and not as trained personnel. Others do not have formal educational backgrounds as well as having the opportunity to attend such courses since they are not organized regularly as done in other parts of the world. Kraemer (2007) explained that young 
superstar athletes have dispelled long-standing misconceptions that strength development should start in the late teens. But much discussion has continued regarding what type of training is most beneficial. Recommendations relative to starting age, choice of exercises, frequency of training, rate of progression, and philosophical strength have been made. Coaches are advised to learn how to individualize the ageappropriate sample training programmes provided, based on the athlete's physical, psychological, and emotional maturity as well as the demands of the sport. Such carefully designed programmes not only improve athletic performance and prepare young athletes for higher competitive levels, but they also help to decrease the incidence of injury along the way.

Corbin (1999) stated that skill-related fitness is that aspect of fitness that talks about the quality aspect of physical education and sports, skill development and sport strategies that prepare learners to be active for high-level performance. The ultimate goal of physical fitness is to help young people develop the skill, knowledge, attitudes and behaviour that lead to physically active and healthy lifestyle.

\section{Statement of the Problem}

Heated arguments at stadia during soccer matches about who is the most skillful player are much worrying. Among journalists and other media practitioners, a person who can dribble is considered as a skillful player and should be the first option for a match, forgetting the fact that, in high level performance what is considered are skill-related components which dribbling is not part. The non-inclusion into the Ghanaian national teams, of Charles Taylor, a popular player of Accra Hearts of Oak and then to Kumasi Ashanti Kotoko is good example of the problem.

Among the two colts (juvenile) soccer clubs in Ghana, (residential and non-residential) there is a popular opinion among sports fans and connoisseurs' that residential clubs are fitter in terms of skill-related fitness components than non-residential club players in. This assumption has prompted the investigation of this problem to find out whether there would be a significant difference between the two groups of juvenile soccer clubs' skill-related fitness levels.

\section{Purpose of the Study}

The purpose of the study is to find out whether there are differences in the skill-related fitness levels of residential and non-residential juvenile soccer clubs in Central and Greater Accra Regions of Ghana.

\section{Research Questions}

1. Is there any relationship between residential status and development of the skill-related fitness components?

2. What is the difference in agility levels between residential and non-residential juvenile soccer clubs in Central and Greater Accra Regions of Ghana?

3. What is the difference in balance levels between residential and non-residential juvenile soccer clubs in Central and Greater Accra Regions of Ghana?

4. What is the difference in coordination levels between residential and non-residential juvenile soccer clubs in Central and Greater Accra Regions of Ghana?

5. What is the difference in power levels between residential and non-residential juvenile soccer clubs in Central and Greater Accra Regions of Ghana?

6. What is the difference in reaction time levels between residential and non-residential juvenile soccer clubs in Central and Greater Accra Regions of Ghana?

7. What is the difference in speed levels between residential and non-residential juvenile soccer clubs in Central and Greater Accra Regions of Ghana?

\section{Methodology}

The study is a quantitative research which seeks to investigate relationships between two or more variables and analyze resultant data as well as accepting derived conclusions

The rationale behind the adoption of this design is that numerical data were collected and analyzed from direct testing of respondents and paper and pencil instruments used as well to give empirical evidence to juvenile soccer coaches; as to the types of quality training programmes they could adopt and the impact of age differences on training. The design also intended to bring the differences in training that could affect 
skill-related fitness among colts clubs in Ghana as well as informing coaches about attention given to training programmes of residential and non- residential colts clubs in Ghana that could improve performance. Finally differences existing in components of skill-related fitness among the colts clubs were established between residential and non-residential clubs in Ghana.

Central and Greater Accra Regional male juvenile clubs regulations state that, each club shall register 25 players for a soccer season. This represents a total of 45 non-residential and two residential clubs in Central Region alone, and 70 non-residential and 3 residential clubs from Greater Accra regions of Ghana. This population is made up of 3000 juvenile male players between the ages 12-17years.

The following procedures were adopted to sample respondents for the test. Purposive, random and stratified sampling techniques were used. Purposive sampling was used because of the limited numbers of residential juvenile soccer clubs available. This method was used for the residential clubs only, since they were the only established ones currently in full operation. The stratified sampling technique was also adopted as a result of the age and sex category involved. Simple random sampling was also used because of the population involved so as to give each player the opportunity to be selected. Two clubs each were sampled from the residential and non- residential clubs in the selected regions.

A total of 15 players each from the residential and non-residential clubs representing 60\% of each group form the sampled size out of which a test group of 10 players in each age category took the test in the selected regions. Sampling for the test was conducted through the simple random sampling method from their registration numbers. A total of 60 players each from the residential and non-residential were used for the final test.

By simple random sampling, a table of random numbers was used from their registered club numbers as they appeared in order of registration. This was made of boy's juvenile clubs; hence 150 subjects were tested.

These criteria were selected to give the study an external validity factor that would allow the results to be generalized to the population of male juvenile soccer players between the ages of 12-17years.

The independent t-tests were used to determine differences in means in the six skill-related fitness components between residential ad non-residential juvenile soccer clubs and chi square to establish relationships. A descriptive statistics was run.

\section{Results/Discussion \\ Question 1: Is there any Relationship between Residential Status and Development of the Skill- Related Fitness Components?}

\section{Table 1}

\section{Bivariate Correlation Analysis of Residential Status and Skill-Related Fitness Components.}

\begin{tabular}{|l|l|}
\hline Test & Residential status (Pearson r.) \\
\hline Agility &.$- .642^{* *}$ \\
\hline Dynamic Balance & $-.229 *$ \\
\hline Coordination & -.149 \\
\hline Power & -.054 \\
\hline Reaction time & $.598^{* *}$ \\
\hline Speed & $.219 *$ \\
\hline
\end{tabular}

** Significant at $0.01 *$ significant at 0.05

The non-residential respondents developed their dynamic balance faster than their residential counterparts. ( $\mathrm{r}$ $=-.229, \mathrm{p}<0.05)$ 
There is a positive relationship between residential status and reaction time which was not significant. $(\mathrm{r}=$ $.598, \mathrm{p}>0.05)$

There is a negative relationship between residential status and agility which was not significant. $(r=-.642, p$ $>0.05)$

There was no relationship between residential status and development of coordination. $(\mathrm{r}=-.149)$. This means that residential status of respondents has no influence on the development on the skill of coordination.

There was no relationship between residential status and development of power. $(r=-.054)$. The development of power is not influenced by residential status.

\section{Question 2: What is the Difference in Agility Levels between Residential and Non-Residential Juvenile Soccer Clubs in Central and Greater Accra Regions of Ghana?}

Independent t- test analysis conducted on residential and residential respondents on their agility level and is presented on table 2 .

Table 2 Independent t-test of two groups in agility (Illinois Agility Run)

\begin{tabular}{|l|l|l|l|l|l|l|}
\hline & $\begin{array}{l}\text { Residential } \\
\text { Status }\end{array}$ & $\mathrm{N}$ & Mean & $\mathrm{T}$ & $\mathrm{P}$ & $\mathrm{p}_{(0.05}$ \\
\hline Agility Test Score & $\begin{array}{l}\text { Non- } \\
\text { residential }\end{array}$ & 60 & 17.4197 & $\begin{array}{l}8.94 \\
0\end{array}$ & .000 & $\mathrm{~S}$ \\
\cline { 2 - 7 } & Residential & 56 & 15.7496 & & \\
\hline
\end{tabular}

$\mathrm{S}=$ significant $\mathrm{NS}=$ not significant .

Non-residential player acquire the skill of agility better than their residential counterparts and the difference was significant. This could be attributed to the fact that soccer performance depends upon a myriad of factors such as geotechnical/biomechanical, tactical, mental and physiological areas as mentioned by Stolen (2005).

According to Whitmore \& Gallwey, (2009) social skills development is an essential part of quality training which cannot be left out if the youth are to be given a better foundation. Most youth start playing soccer indoors at their homes with siblings and friends. They would have gone out in the neighborhood and played street ball and had lots of fun sweating and competing and could have developed their agility component better than their residential counterparts.

The non-residential players might have gained these advantages in agility through their training programme. Stephens (2011) mentioned that agility drills and routines form a vital part of everyday training for a successful soccer player. They help stimulate reflexes and increase agility, depending on a coach's approach. She further explained that Training for agility requires an integrated approach of balance, coordination, speed and strength and a coach should take each of these factors into consideration separately by focusing on each, as well as using overall agility drills.

\section{Question 3: What is the Difference in Balance Levels between Residential and Non-Residential Juvenile Soccer Clubs in Central and Greater Accra Regions of Ghana?}

Independent $\mathrm{t}$ - test analysis was conducted on the difference in balance levels between residential and nonresidential juvenile soccer clubs in central and greater Accra regions of Ghana and are presented on Table 3.

Table 3 Independent t-test of Two Groups in Agility (Bass Test of Dynamic Balance) 


\begin{tabular}{|c|c|c|c|c|c|c|}
\hline & $\begin{array}{l}\text { Residential } \\
\text { Status }\end{array}$ & $\mathrm{N}$ & Mean & $\mathrm{T}$ & $\mathrm{P}$ & $\mathrm{p}_{(0.05}$ \\
\hline \multirow[t]{2}{*}{$\begin{array}{l}\text { Bass test of } \\
\text { Dynamic Balance }\end{array}$} & $\begin{array}{l}\text { Non- } \\
\text { residential }\end{array}$ & 60 & 51.9200 & \multirow[t]{2}{*}{$\begin{array}{l}2.53 \\
4\end{array}$} & \multirow[t]{2}{*}{.013} & \multirow[t]{2}{*}{$S$} \\
\hline & Residential & 56 & 47.8393 & & & \\
\hline
\end{tabular}

$\mathrm{S}=$ significant $\mathrm{NS}=$ not significant.

From Table 3, it revealed that the differences in mean score between non residential and residential respondents as observed in balance was significant $(\mathrm{t}=2.532, \mathrm{p}=.013,<0.05)$.

Jackson and Walden (2003) opined that the visceral and glandular can be screened, as well as nutritional and lifestyle habits. For example, a soccer player with exhausted adrenals and poor diet will have compromised stability at $\mathrm{T}_{12}$ areas. He is constantly rotating his trunk (when shooting, turning, cutting and faking) during a game. Again a combination of an exhausted adrenal gland and inhibition stabilizers, due to poor nutrition or adrenal stress will compromise stability in this area and cause the player back pain due to abdominal inhibition.

Sherrill (1993) mentioned that input from semicircular canals and sacs are needed in all kinds of balance. This is because the head moves in many ways during both static and dynamic balance, and a test of balance in position will not yield data that are generalized to other positions.

The difference as observed in the test could be as result of the factors such as physical factors, psychological, or external factors according to Mike Walden (2003).

Question 4: What is the Difference in Coordination Levels between Residential and Non-

Residential Juvenile Soccer Clubs in Central and Greater Accra Regions of Ghana?

Independent t-test was conducted to ascertain the difference in coordination levels between residential and non-residential juvenile soccer clubs in the central and greater Accra regions of Ghana and is presented on table 4.

Table 4 Independent t-test of Two Groups in Coordination (Stick Test of Coordination)

\begin{tabular}{|l|l|l|l|l|l|l|}
\hline & $\begin{array}{l}\text { Residential } \\
\text { Status }\end{array}$ & $\mathrm{N}$ & Mean & $\mathrm{T}$ & $\mathrm{P}$ & $\mathrm{p}_{(0.05}$ \\
\hline $\begin{array}{l}\text { Stick Drop Test } \\
\text { of Coordination }\end{array}$ & $\begin{array}{l}\text { Non- } \\
\text { residential }\end{array}$ & 60 & $\begin{array}{l}3.633 \\
3\end{array}$ & $\begin{array}{l}1.6 \\
04\end{array}$ & $\begin{array}{l}.11 \\
1\end{array}$ & NS \\
\cline { 2 - 5 } & Residential & 56 & $\begin{array}{l}2.875 \\
0\end{array}$ & & & \\
\hline
\end{tabular}

$\mathrm{S}=$ significant $\mathrm{NS}=$ not significant.

From Table 4, there was no significant difference in their mean score in coordination and the difference observed was by chance. According to Lieberman (1999) coordination, like all other abilities, can be general and specific, related to precise skill movements. There is no doubt that a high level of coordination makes it easier to learn specific coordination. The term coordination is also applied to a complex physical actions controlled by the brain and nervous system, such as catching a ball, playing a piano, or ridding on a roller skates.

The body's sensory systems, such as sight, touch, and balance and muscular, all work all work together to make the movements smooth and skillful. Various parts of the body of the body may be involved such as eye foot coordination, kicking and catching a ball. The breastroke in swimming can help in demonstrating what is meant by coordination in that a person can learn the arm stroke and the kick separately. However, a maximum performance will result only if these two parts were separately learnt are combined in a smooth flow of movement.

Corbin, Lindsey, Welk, and Corbin (2002) defined coordination as the ability to use the body parts to perform motor task smoothly and accurately. The non significant differences observed in the two categories of juvenile clubs mean scores could also be attributed to factors such as environmental, social, physical 
abilities psychological ability, current status and other factors that are natural and that go beyond the coach and players control as mentioned by Brain (1997) which were almost the same.

\section{Question 5: What is the Difference in Power Levels between Residential and Non-Residential Juvenile Soccer Clubs in Central and Greater Accra Regions of Ghana?}

Independent sample t-test was conducted on the difference in power levels between residential and nonresidential juvenile soccer clubs in the central and greater Accra regions of Ghana and the results are presented on table 5.

Table 5 Independent t-test of two groups in Power (Vertical Jump Test)

\begin{tabular}{|l|l|l|l|l|l|l|}
\hline & $\begin{array}{l}\text { Residential } \\
\text { Status }\end{array}$ & $\mathrm{N}$ & Mean & $\mathrm{T}$ & $\mathrm{P}$ & $\begin{array}{l}\mathrm{p}_{(0.0} \\
5\end{array}$ \\
\hline $\begin{array}{l}\text { VerticalJump } \\
\text { Test of Power }\end{array}$ & $\begin{array}{l}\text { Non- } \\
\text { residential }\end{array}$ & 60 & 7.9863 & &. & NS \\
\cline { 2 - 4 } & Residential & 56 & 7.8321 & 81 & 6 & \\
& & & & & \\
\hline
\end{tabular}

S= Significant NS $=$ Not Significant

There were no significant differences in the mean score in power and the difference observed was by chance. The insignificant difference observe in mean score as observed in power of both categories of soccer players could be attributed to factors such as drugs, diet, age, somatotype and personality. Again others like physical factors, psychological, or external factors can affect performance, Walden (2003).

Power is a combination of speed and strength and is both health-related and skill-related. Most experts classify power as a skill-related component because it is partially dependent on speed. On the other hand, power is also dependent on strength and can be classified as health-related component to the extent that strength is involved. Thus, power falls between the two distinct groups of fitness attributes according to Corbin (2003). Corbin (2003) explained further that there is probably no one best training programme for developing power, but the law of specifity applies. Power requires both strength and speed, therefore increasing one without the other limits power. Football players might benefit more by achieving less strength and more speed. These factors enumerated above could have accounted for the similarities in the scores of the two juvenile soccer groups.

\section{Question 6: What is the Difference in Reaction Time Levels between Residential and Non- Residential Juvenile Soccer Clubs in Central and Greater Accra Regions of Ghana?}

Independent t-test was conducted on reaction time levels between residential and non-residential juvenile soccer clubs in central and greater Accra regions of Ghana and the results are presented on table 6.

Table 6 Independent t-test of two groups in Reaction Time

\begin{tabular}{|c|c|c|c|c|c|c|}
\hline & $\begin{array}{l}\text { Residential } \\
\text { Status }\end{array}$ & $\mathrm{N}$ & Mean & $\mathrm{T}$ & $\mathrm{P}$ & $\begin{array}{l}\mathrm{p}_{(0.0} \\
5\end{array}$ \\
\hline \multirow[t]{2}{*}{ Stick Drop Test } & $\begin{array}{l}\text { Non- } \\
\text { residential }\end{array}$ & 60 & 7.5000 & \multirow{2}{*}{$\begin{array}{l}- \\
7.75 \\
9\end{array}$} & \multirow[t]{2}{*}{.000} & \multirow[t]{2}{*}{$S$} \\
\hline & Residential & 56 & 18.5357 & & & \\
\hline
\end{tabular}

$\mathrm{S}=$ significant $\mathrm{NS}=$ not significant

From Table 6, reaction time means of residential respondents on the other hand were higher than their non residential counterparts. The $\mathrm{t}$-test shows a significant difference $(\mathrm{t}=-7.759, \mathrm{p}=-0.000, \mathrm{p}=<0.05)$. Therefore 
residential respondents had better reaction time than their non residential counterparts. The significant difference observed in their mean score in the two categories of juvenile soccer player may be attributed to the factors explained below. According to Brain Mac (1997) reaction time is an inherent ability, but overall response time can be improved by practice. Coach and athletes need to analyze the type of skill and the requirements of their sport and decide where overall response gains can be made. Consider the following: Detecting the cue, detecting relevant cues- (in a soccer game a goalkeeper should learn to analyze body language at penalties), decision making, and change in attention focus (being able to switch quickly from concentration on the opponent to concentration on the field of play in invasion games, as well as controlling anxiety, creating optimum levels of motivation - 'psyching up', and finally a warm up to ensure the sense organs and nervous system are ready to transmit information and the muscles to act upon it.

Brain(1997) in his detailed explanations mentioned that factors that may influence a players response time are stage of learning, psychological state, level of fitness, number of possible responses, time available, intensity of the stimuli, anticipation, experience, health, body temperature -colder the slower, personality extroverts react quicker, state of alertness, length of neural pathways' performance.

\section{Question 7: What is the Difference in Speed Levels between Residential and Non-Residential Juvenile Soccer Clubs in Central and Greater Accra Regions of Ghana?}

Independent sample t-test was conducted on the speed levels between residential and non-residential juvenile soccer clubs in central and greater Accra regions of Ghana and the results are presented on table 7.

\section{Table 7 Independent t-test of two groups in Speed Levels (Running Test of Speed)}

\section{$\mathrm{S}=$ significant $\mathrm{NS}=$ not significant}

\begin{tabular}{|l|l|l|l|l|l|l|}
\hline & $\begin{array}{l}\text { Residential } \\
\text { Status }\end{array}$ & $\mathrm{N}$ & Mean & $\mathrm{T}$ & $\mathrm{P}$ & $\begin{array}{l}\mathrm{p}_{(} \\
0.0 \\
5\end{array}$ \\
\hline $\begin{array}{l}\text { Running Test of } \\
\text { Speed }\end{array}$ & $\begin{array}{l}\text { Non- } \\
\text { residential }\end{array}$ & 60 & 23.7167 & & .019 & $\mathrm{~S}$ \\
\cline { 2 - 6 } & Residential & 56 & 24.9911 & 2. & & \\
& & & & 3 & & \\
& & & & 8 & & \\
& & & & & \\
\hline
\end{tabular}

Speed level means of residential respondents on the other hand were higher than their non residential counterparts. The $\mathrm{t}$ - test shows that this difference in means are significant $(\mathrm{t}=-2.388, \mathrm{p}=0.019$, $\mathrm{p}<0.05)$.Therefore residential respondents had better speed than their non residential counterparts.

According to Whitmore (2009) speed of a soccer player is a complex one if compared with that of a 100 meter runner, this is a combination of several skills, like speed of recognition, reaction speed and action speed.

Most of the qualities that make a player fast come from concentration and power acquired from game specific techniques that are developed with constant on the ball activities.

Stephens (2011) mentioned that speed training can involve a resisting force, or movement assistance, so that your legs can learn how to move more quickly. Resistance can be in the form of a belt and ropes, pulling back as you try to run forward, running in water or sand, running uphill, or using a parachute. Assisted training can be in the form of being pulled forward more quickly than you are able to move on your own. This can include using gravity by running downhill or with a pulling force, such as a tension band and belt, to pull you forward. 
A soccer player does a lot of movements in various planes, therefore the difference obtained by the residential soccer players' mean score could also be explained as a result of their high levels of velocity. Velocity is the speed in which you can change directions. This skill is dependent on your speed and agility. Once you have developed each of these, you can expect an associated increase in velocity. Practicing changing directions as quickly as possible with stop and start movement will help you obtain the desired results (Stephen, 2011)

Table 8 Independent t-test on Impact of Age Differences on Development of Skill-Related Fitness through Training

\begin{tabular}{|c|c|c|c|c|c|c|}
\hline & $\begin{array}{l}\text { Age of } \\
\text { Part's }\end{array}$ & $\mathrm{N}$ & Mean & $\mathbf{T}$ & $\mathbf{P}$ & $\mathrm{P}(0.05)$ \\
\hline \multirow[t]{2}{*}{ Agility test score } & $11-15$ & 73 & 16.7038 & \multirow[t]{2}{*}{1.117} & \multirow[t]{2}{*}{.243} & \multirow[t]{2}{*}{ NS } \\
\hline & $16-20$ & 42 & 16.4090 & & & \\
\hline \multirow{2}{*}{$\begin{array}{l}\text { Bass Test of } \\
\text { Dynamic Balance }\end{array}$} & $11-15$ & 73 & 48.4767 & \multirow[t]{2}{*}{-2.251} & \multirow[t]{2}{*}{.02} & \multirow[t]{2}{*}{$S$} \\
\hline & $16-20$ & 42 & 52.3071 & & & \\
\hline \multirow{2}{*}{$\begin{array}{l}\text { Stick Test of } \\
\text { Coordination }\end{array}$} & $11-15$ & 73 & 2.6575 & \multirow[t]{2}{*}{-3.588} & \multirow[t]{2}{*}{.000} & \multirow[t]{2}{*}{$S$} \\
\hline & $16-20$ & 42 & 4.3571 & & & \\
\hline \multirow{2}{*}{$\begin{array}{ll}\text { Vertical } & \text { Jump } \\
\text { Jest(power) } & \end{array}$} & $11-15$ & 73 & 7.5284 & \multirow[t]{2}{*}{-3.974} & \multirow[t]{2}{*}{.000} & \multirow[t]{2}{*}{$S$} \\
\hline & $16-20$ & 42 & 8.5626 & & & \\
\hline \multirow{2}{*}{$\begin{array}{l}\text { Stick Drop Test } \\
\text { (reaction time) }\end{array}$} & $11-15$ & 73 & 14.4521 & \multirow[t]{2}{*}{2.386} & \multirow[t]{2}{*}{.019} & \multirow[t]{2}{*}{$S$} \\
\hline & $16-20$ & 42 & 10.2619 & & & \\
\hline \multirow{2}{*}{$\begin{array}{l}\text { Running Test of } \\
\text { Speed }\end{array}$} & $11-15$ & 73 & 23.6370 & \multirow[t]{2}{*}{-3.384} & \multirow[t]{2}{*}{.001} & \multirow[t]{2}{*}{$S$} \\
\hline & $16-20$ & 42 & 25.4762 & & & \\
\hline
\end{tabular}

Respondents within the age category of 16-20 had a higher mean score in four of the six skill-related tests(dynamic balance, coordination, power and speed), however, in agility and reaction time the respondents in age category 11-15 had a higher mean score than their counterparts in the other age category (see table 8). A t- test conducted to ascertain if the differences observed in the means were significant showed that, they were all significant except in the agility test. The implication therefore is that respondents in age category 16-20 showed a better development in the skill-related components of dynamic balance, coordination, power and speed than their lower aged counterparts. However, respondents in age group 11-15 had a better reaction time than their counterparts in the higher aged category. These results give credence to the idea raised by Kraemer W, (2007) who says coaches are advised to learn how to individualize the ageappropriate sample training programmes provided, based on the athlete's physical, psychological, and emotional maturity as well as the demands of the sport. Such carefully designed programmes not only improve athletes' performance and prepare young athletes for higher competitive levels, but they also help to decrease the incidence of injury along the way.

Youth players with a greater relative age are more likely to be identified as "talented" because of the likely physical advantages they have over their "younger" peers.

A further correlation analysis on the two group's six components of fitness were run to ascertain if there is a difference between them as well as the mean scores of responses collated from questionnaires collected.

A bivariate correlation analysis of residential status of skill-related fitness components between the two groups under discussion are as follows. 
There is a positive modest relationship between the residential status and development of the components of speed. That is residential students have high scores for speed than their counterparts who are non-residential $(\mathrm{r}=.219, \mathrm{p}<0.05)$

The results also show a negative modest relationship between residential status and the development of dynamic balance, an indication of non-residential respondents developed their dynamic balance faster than their residential counterparts. $(r=-.229, \mathrm{p}<0.05)$. There is also a positive relationship between residential status and reaction time which was not significant. $(\mathrm{r}=.598, \mathrm{p}>0.05)$ as shown in the table below.

A greater number of the residential respondents find their training normal and able to cope, while only about a third of the non-residential respondents share similar sentiment. This means training programmes of nonresidential clubs are organized differently from the residential counterparts. Furthermore, too many games within a short period of time can also lead to poor performance and increase the chances of illness or injury among residential clubs. This observation is supported by the assertion made that; the goal of time management should not be to eliminate leisure time, but to be eliminating life's real time wasters. How well one plans his time determines ones success in any physical challenge (Powers, 1999)

The practical test conducted revealed high scores in power, coordination, balance and agility for nonresidential clubs than their counterparts. These results could be attributed to factors like age, type of training and food that might have influenced the results.

This suggests that non-residential teams do not have the technical personnel who understand and appreciate the importance of other phases like mini games, fun games and set pieces in training. They as well spent much time organizing, instructing and directing players. From the responses gathered it is evident that nonresidential clubs spent more time at training than their counterpart, which could lead to overtraining and diminished performance. The assertion by Bilton (2002) that heavy and prolonged training may bring about what is known as overtraining syndrome, staleness or burnout could affect the non- residential teams.

This position did not show in the practical test in all the components of skill-related fitness in table 7 . It means the non-residential clubs do well to manage their time and are able to do away with waste in their sessions.

Further explanation that could be given to this observation is that insufficient equipment and management could be a problem to the non-residential clubs, and as a result the little is over stretched and well managed, even though a player for example will have to wait for other colleagues to have their turns with a ball before he can practice a drill or a new skill taught with the ball, hence the long hours spent at training sessions.

Non-residential clubs did well in four components yet only one has a negative modest relationship between residential status and the component, i.e. development of dynamic balance. The non-residential respondents developed their dynamic balance faster than their residential counterparts.

A cross tabulation analysis on how players are treated outside the field of play revealed that, logistical supports like academics, food, financial and rest are major factors militating against non-residential clubs officials as compared to that of their residential counterparts . Fifty-six (56) respondents, representing (100\%) non-residential players are not fed at camp as compared to 50 residential respondents, representing (83.3\%) who are supported with food. It is suggested that if one wants to be a professional soccer player (and a good one, at that) every small detail that could improve one's performance should be taken into consideration. Nutrition, as a whole, is not a small detail in soccer; it is extremely important to a player (Orlian, 2010).

The practical tests showed high scores for non-residential clubs in four components as indicated in earlier discussions, it is evident that those at home receive nutritious meals than their residential counterparts hence the better performance.

Reacting to the question as to whether players are given holidays to rest to recover from injuries and other physiological challenges, (50) residential respondents representing $(89.2 \%)$ affirmed that they are given at least one and half months holidays to rest (see table 11). This notion is supported by Meeks (2003) that 
adequate rest and sleep are essential, to keep mental alertness, maintenance of good disposition, physical wellness and maintenance of proper growth hence the positive relationships in speed and reaction times for residential players.

A t-test analysis on the components of skill-related fitness indicated higher mean scores for non-residential clubs in agility, balance, coordination and power than their residential counterparts. This is also revealed in the cross tabulation survey that, 45 non-residential respondents, representing (75\%) believe that their main focus is training as compared to 38 respondents representing (67.8\%) residential players who also confirmed that their programme concentrated mainly on training.

To achieve the best possible performance, training has to be formulated according to the principles of periodisation. Furthermore, growth and development phase of life has impact on training. The traininginduced changes observed in various physiological and biochemical parameters can be attributed to appropriate load dynamics. Body composition has an important role in playing soccer. Since in soccer lots of physical contacts occur .and many movements and skills are involved and a high level of physical demand is required which demands for aerobic fitness as well as anaerobic one (Manna, et al, 2009). The non residential clubs' high scores in the practical session could have been influenced by growth, body composition and developmental phase of life and not on the principles of periodisation and training as posited by (Manna, et al, 2009).

Training for longer periods could also have influenced these results. This is so because the mean age of nonresidential players is 15.08 as compared to 13.86 of the residential clubs from table 13 below. It is evidently clear that the components in which the non- residential clubs had higher scores (power, balance, agility and coordination) demands social and chronological growth for its sustenance.

\section{Conclusions}

From the differences observed in four components in the non-residential clubs thus, power, coordination, balance and agility, only two were significant and could influence the results positively (agility and balance). The residential players also showed significant influence in speed and reaction time than their nonresidential counterparts. The number of programmes residential clubs go through at training tends to influence their speed and reaction time, power, coordination, balance and agility negatively because they look younger and cannot cope with the physical demands of the test as compared to their counterparts at home who look stronger and athletic.

It was observed that age category 16-20 years shows high scores in power, speed, coordination, balance and agility than their counterparts in category 11-15years who showed high scores only in reaction time. This proved that non-residential clubs have players who are older and stronger than their counterparts. There is an interesting phenomenon about the non-residential clubs that seem to have an edge over the residential players. This is about equipments, terrains and fields that non-residential players use and train with. The players learn to play in difficult and critical situations which tend to improve components they excelled

Moreover the search revealed that residential status does not influence agility, coordination and power but rather speed and reaction time. Non-residential status influence dynamic balance positively than any other component in skill-related fitness.

Finally it has been observed that non-residential clubs go through long training hours that influences better results and other factors like diet, body composition and development of life, have influence on power, coordination, agility and balance than their counterparts, even though two components out of the four are not significant.

\section{Recommendations}

From the research findings and conclusions above the following recommendations are offered:

1 Coaches are to manage their time and facilities effectively and appropriately to ensure total fitness in all components. 
Coaches should update their knowledge on modern strategies in training youth players as well as identifying their strengths and weakness in skill-related fitness and make use of them appropriately.

3 Managers of clubs should make feeding of players a policy even if players are not staying in the designated premises to ensure total physical development.

4 Residential club coaches should give attention to programmes that develops power, balance and coordination; therefore their players should be allowed to train at different terrains that are unfamiliar, like rough and undulating fields since that could improve their ability to withstand pressure as well as developing if not all most of the components of skill-related fitness.

5 Non-residential clubs should as well ensure that their training programmes would develop speed and reaction time if players are to develop in all components of skill-related fitness.

6 Finally non-residential clubs should use players of the same age category to ensure steady development.

\section{References}

[1] Afranie, K. (2010). Coach Afranie proposes regional juvenile teams. $\quad$ Retrieved April 29, 2011 from http:www.ghanaweb.com/Ghana Homepage/Sports Archive/artikel.php?ID=179491

[2] Brian, M. (1997). Improving reaction speed, Retrieved May 12, 2011 from http://www.brianmac.

[3] Corbin, C. B. Lindsey, R. Welk, G .I. and Corbin, W. R. (2002). Concepts of fitness and wellness: A Comprehensive Lifestyle Approach (4th Edition).Boston:McGraw-Hill Companies.Inc.

[4] Hopkins, W.G. (1998). A new view of statistics: Internet Society for Sport Science. Retrieved from http://sportsci.org/stats/.

[5] Hopkins, W.G. PhD. Measurement of training in competitive sports. Retrieved April 16,2007.from http://.sportsci org./jour/ 9804/wgh.html\#behavior.

[6] Jackson, W. A. and Walden. M. (2003). Understanding your health ( ( $^{\text {th }}$ edition) Boston, McGraw Hill.

[7] Kellis, E. (2007). Biomechanical characteristics and determinants of instepsoccer kick. Retrieved May 5, 20 from $\quad$ http://www.jssm.org/vol6/n2/1/v6n2-1pdf.pdf http://sportsci.org/stats/

[8] Kraemer, W. (2007).Strength \& conditioning for the young athlete. Retrieved May 5, 2009 from

[9] Sherrill, C. (1993).Adapted physical activity, recreation and sports-cross disciplinary and lifespan. Dubuque, Iowa: McGraw-Hill Companies Inc.

[10] Stephens, K. (2011).Velocity speed \& agility training. Retrieved May 12, 2011 from http://www.livestrong.com/article/159307-velocity- speed-agility- training/\#ixzz1Pm0cb3ZC.

[11] Lieberman, L. J. (1999). Sports in life. Retrieved 14 June 2010from http://.clecenter.gallaudet.edu.

[12] Long, A. (2007). Physical education and sports. Boston: Massachusetts, USA, McGraw Hill.

[13] Manna, I. (2009). Effect of Training on physiological and biochemical variables of soccer $\begin{array}{llll}\text { players of different age groups. Retrieved May } & 21, & 2010 & \text { from }\end{array}$ http://journals.tums.ac.ir/upload_files/pdf/15033.pdf

[14] Meeks, L. Heit, P. \& Page, R, (2003). Comprehensive school health education, totally awesome strategies for teaching health. New York. McGraw-Hill.

[15] Mike. N, (2003). Soccer Nutrition. Retrieved May 10, 2010 from Error! Hyperlink reference not valid..

[16] Powers, K. Scott, and Howley, Edward T (1994) Exercise physiology: $\quad$ Theory and Application to fitness and performance. (2nd ed.) Dubuque, Win C. Brown Cons. Inc.

[17] Siedentop, D. (2001).Introduction to physical education:fitness and sports. (4 ${ }^{\text {th }}$ Edition) California. Mayfield Publishing Company.

[18] Stølen,T. Chamari, K. Castagna, C. and Wisløff, U. Physiology of soccer. Retrieved April 30, 2010 from http://www.ncbi.nlm.nih. gov/pubmed/15974635 
[19] Stephen, K. (2001). Soccer coaching-how to coach soccer in 3 easy steps. Retrieved May 5, 2010 from http://www.soccermastermind.com 2009/01/soccer-coaching-how-to- coach- soccer-in3-easy-steps/

[20] Sherrill, D.L. (1993). Biomechanical considerations for training the youth athlete. Retrieved from http://www.strengthpro.com/asts/ASTS2007lect_bios.pdf.

[21] Walden, M. (2010).Transfer of skills Retrieved on April 18, 2010 fromhttp://www.teachpe.com/sports_psychology/skill_transfer.php

[22] Whitmore, J. \& Gallwey, T. Coaching Fundamentals of youth soccer, building skills and techniques: Retrieved July 15, 2009 from http://www.soccertrainingskills.com/YouthSoccer.html 